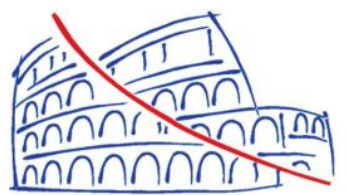

THE SECOND

WORLD

\title{
Landslides Induced by Historical and Recent Earthquakes in Central-Southern Apennines (Italy): A Tool for Intensity Assessment and Seismic Hazard
}

\author{
Eliana Esposito, Luca Guerrieri, Sabina Porfido, Eutizio Vittori, \\ Anna Maria Blumetti, Valerio Comerci, Alessandro M. Michetti, \\ and Leonello Serva
}

\begin{abstract}
Analysis of distribution of landslides (rock falls and coherent slides), induced by 12 moderate to strong earthquakes occurred in the last three centuries in Central-Southern Apennines, has permitted to investigate the relationship of their maximum distance versus magnitude and ESI epicentral intensity.

For coherent slides, the correlation of magnitude or ESI intensity versus distance is fairly good and consistent with global datasets. Instead, rock falls show a less evident correlation with distance. We stress here the usefulness of such relationships to define the expected scenario of earthquake-induced landslides. However, the data base needs to be improved and enlarged to allow more robust estimates.
\end{abstract}

Keywords

Earthquake-induced landslides • Intensity scales • Central-Southern apennines

\section{Introduction}

The inner sector of Central-Southern Apennines is the most seismic sector of the Italian territory (Fig. 1), characterized in historical times by a number of earthquakes with magnitude around 7 and frequent moderate earthquakes (magnitude around 6).

Events of $M \diamond 6$ typically cause environmental effects (surface faulting, landslides, liquefactions, ground cracks, hydrological anomalies, etc.) that are a significant

E. Esposito $(\star) \cdot$ S. Porfido

Istituto per l'Ambiente Marino e Costiero, CNR, Calata Porta di Massa, Naples 80133, Italy

L. Guerrieri • E. Vittori • A.M. Blumetti • V. Comerci • L. Serva Dipartimento Difesa del Suolo, Servizio Geologico d'Italia, ISPRA, Via V. Brancati 48, Rome 00144, Italy

A.M. Michetti

Dipartimento di Scienze Chimiche e Ambientali, Università

dell'Insubria, Via Valleggio, 11, Como 22100, Italy independent source of seismic hazard in addition to damages due to ground acceleration.

Many historical documents detail the effects of earthquakes in the Apennines, especially the strong events occurred in the last three centuries, reporting lots of data also on the characteristics of the effects on the natural environment. This extraordinary wealth of information has allowed (1) to identify the most vulnerable regions, i.e., the most prone to hazardous Environmental Effects of Earthquakes (i.e. the effects produced by an earthquake on the natural environment or EEEs) and (2) to evaluate the earthquake intensity (epicentral and local) by means of the ESI intensity scale (Michetti et al. 2007), a recently developed intensity scale only based on EEEs.

This study aims at relating the spatial distribution of seismically-induced landslides with magnitude and with the intensity of the event resulting from the application of the ESI scale. 
Fig. 1 Historical seismicity of Central-Southern Apennines (CPTI 2004). Labels locate the epicentres of the seismic events considered in this study

\section{Background}

\section{Seismotectonic Framework of the Apennines}

The present tectonic structure of the Apennines is the result of Upper Miocene-Lower Pliocene northeast-verging thrust tectonics (Patacca et al. 1990) overprinted by Late Pliocene to Quaternary northeast-southwest crustal extension, migrating in time and space from west to east; the latter is still active now, as demonstrated by seismic (including palaeoseismic) and morphotectonic evidence (Demangeot 1965; Blumetti et al. 1993; Roberts and Michetti 2004). Geodetic data provide velocities (with respect to stable Eurasia) that imply extension rates of 4-5 mm/year across the Apennines (D'Agostino et al. 2008; Devoti et al. 2008).

Historical catalogues (CPTI 2004; Guidoboni et al. 2007) summarize all available information for several moderate to strong earthquakes affecting CentralSouthern Apennines in a time window larger than two millennia, but with good completeness only for the last 500 years.

Seismic hazard maps based on historical seismicity and integrated with paleoseismic evidence locate the areas with highest expected magnitudes (even more than 7) in the inner sector of the Central-Southern Apennines.
Magnitude Versus Landslide Distance: State of the Art

Empirical relationships between earthquake-triggered land- 74 slide distribution and magnitude based on a global database 75 (about 40 events in the period 1811-1980) have been pro- 76 posed by Keefer (1984). These relations were refined by 77 Rodriguez et al. (1999) and Bommer and Rodriguez (2002) 78 using a similar approach based on a larger dataset (almost $80 \quad 79$ earthquakes). The last papers also discuss the potential rela- 80 tion between landslides distribution and MM intensity 81 degrees. The best fit of data is given by polynomial curves 82 of second degree.

Other relationships between magnitude and landslide dis- 84 tance were published for regional areas (e.g. Papadopoulos 85 and Plessa 2000, for Greece).

In Italy, Prestininzi and Romeo (2000) related the maxi- 87 mum distance of ground failures collected in the CEDIT 88 database (that includes landslides, fractures, liquefaction, 89 topographic changes) with MCS epicentral intensities. Other 90 empirical relationships were pointed out in previous papers of 91 the Authors of this note (e.g. Porfido et al. 2002, 2007), where 92 the distribution of the number of landslides with distance 93 appears to follow a negative exponential trend (e.g. 1805 and 94 1980 earthquakes). A similar trend has been highlighted for the 95 2009 earthquake (Guzzetti et al. 2009; Vittori et al. in prep.). 96

\section{ESI 2007 Intensity Scale}

The ESI 2007 intensity scale (Michetti et al. 2007) classifies 98 earthquake intensity based only on Earthquake Environmental 99 Effects (EEE)., either directly linked to the earthquake source or triggered by the ground shaking. EEEs include surface faulting, regional uplift and subsidence, tsunamis, liquefaction, ground resonance, landslides, rock falls and ground cracks.

The definition of the ESI intensity degrees has been the result of a revision conducted by an International Working Group made of geologists, seismologists and engineers. It has been ratified by INQUA (International Union for Quaternary Research) in 2007.

The use of the ESI 2007 intensity scale, alone or integrated with the other traditional scales affords a better picture of the earthquake scenario, because only environmental effects allow suitable comparison of the earthquake intensity both:

- In time: effects on the natural environment are comparable for a time-window (recent, historic and palaeo seismic events) much larger than the period of instrumental record (last century), and

- In different geographic areas: environmental effects do not depend on peculiar socio-economic conditions or different building practices.

\section{6}

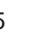
. . (n) (n) (1) 82 84 8 


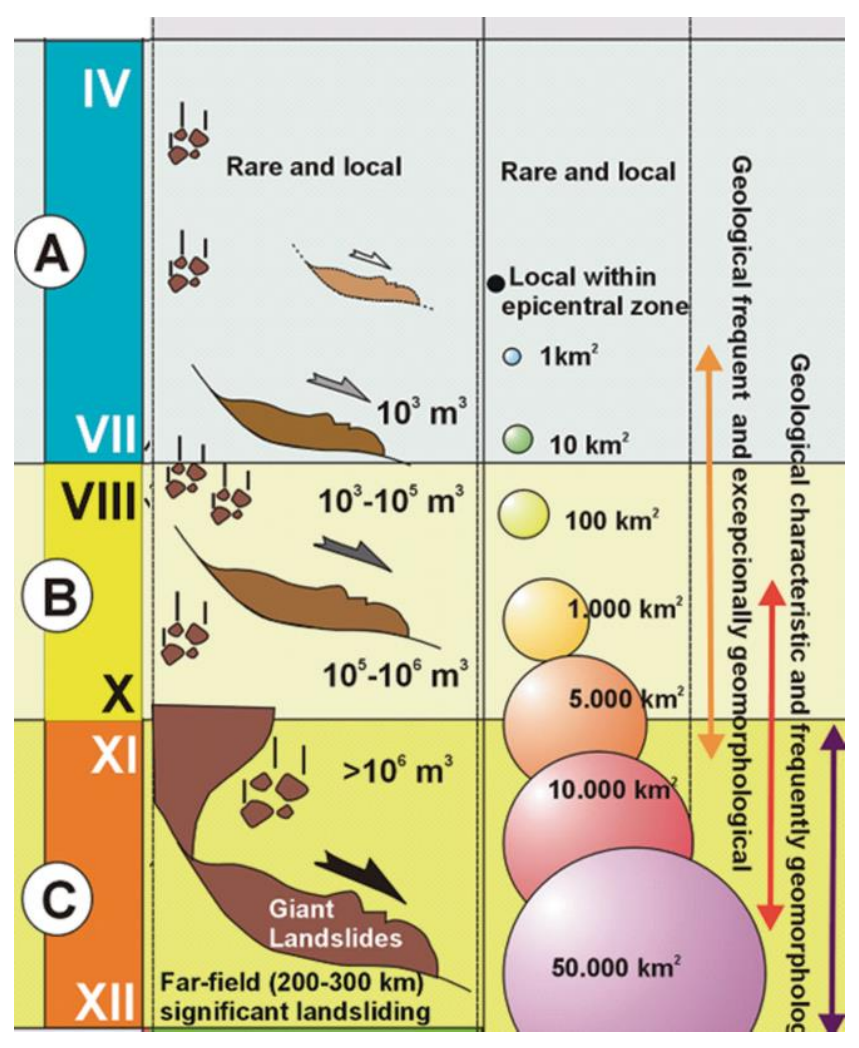

Fig. 2 Schematic picture of the typical landslide size and spatial distribution for ESI intensity degrees ranging from IV to XII (Michetti et al. (2007); Silva et al. (2008))

Thus, the new scale aims at integrating traditional seismic scales:

- For earthquake intensity degree larger or equal to X, when damage-based assessments are extremely difficult (because of tendency to saturation), while environmental effects are still diagnostic;

- In sparsely populated areas, where the effects on manmade structures are lacking and therefore intensity assessments have to be based on the environmental effects, which are the only available diagnostic elements. The occurrence of landslides is expected from intensity IV ESI. The spatial distribution area of secondary effects (including landslides) allow to estimate the ESI epicentral intensity up to XII (Fig. 2). Furthermore, the growing size (volume, area) of slope movements are considered diagnostic elements for the assessment of the ESI local intensity in the range IV to X.

\section{Landslides Versus Intensity in the Apennines}

\section{Landslides Triggered by Selected Earthquakes}

We have taken into account 12 earthquakes occurred in the last three centuries, many of which studied in detail by the Authors for macroseismic purposes, with specific focus on

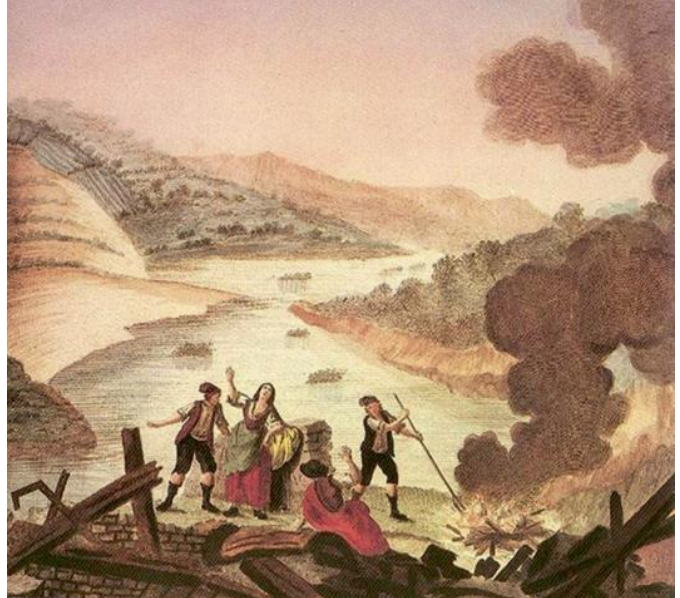

Fig. 3 A landslide triggered by the 1783 Calabrian seismic sequence damned the S. Cristina narrow valleu and formed a temporary lake (Sarconi 1784)

the characterization of Earthquake Environmental Effects (Comerci et al. 2009; Esposito et al. 1998, 2000, 2009; Esposito and Porfido 2010; Guerrieri et al. 2007, 2009; Porfido et al. 2002, 2007, 2011; Serva et al. 2007; Vittori et al. 2000, 2011) (Fig. 3).

The 1783 Calabrian seismic sequence (Ms $1 / 46.9 ; I_{0} 1 / 4$ XI MCS; I $\mathrm{I}_{0}^{1 / 4}$ X-XI ESI) was characterized by a 3 years long sequence and five main shocks generated by individual fault segments of regional WNW-ESE trends. The 1783 multiple event started at the beginning of February and went on until the end of March, reaching a release of energy on March 28 with assessed macroseismic magnitude $M 1 / 4$ 6.9. More than 30,000 lives were lost and 200 localities were completely destroyed by the February 5 main shock. The epicentral area was located on the Gioia Tauro plain, at the western foot of the northern Aspromonte mountain.

The shock produced spectacular ground effects, both primary and secondary, such as tectonic deformations, ground fractures, liquefactions phenomena, tsunamis, hydrological changes and diffuse landslides of large size, which in most cases dammed the rivers creating more than 200 new temporary lakes (Porfido et al. 2011). A great density of mass movements occurred in the area bounded by Santa Cristina d'Aspromonte, Molochio-Cittanova and Palmi (Cotecchia et al. 1986). The most common landslides were earth-block type, translational and rotational movement affecting the PlioPleistocene deposits of Gioia Tauro Plain (Cotecchia et al. 1986). Nevertheless, a reliable dataset of rock fall distribution is not available.

The 1805 July 26 Molise earthquake (Ms $1 / 46.6 ; \mathrm{I}_{0} 1 / 4 \mathrm{X}$ MCS; $I_{0} 1 / 4$ X ESI) affected mostly the Molise region, where at least 30 municipalities, located in the Bojano plain and the eastern foot of the Matese massif, were nearly totally destroyed (Esposito et al. 1987). 
About one hundred seismically induced environmental effects are known for the 1805 earthquake mostly in the near-field area although some were reported as far as $70 \mathrm{~km}$ from the epicentre (Esposito et al. 1987; Porfido et al. 2002, 2007; Serva et al. 2007).

The earthquake triggered at least 26 slides: mainly rock falls, topples, slumps, earth flows and slumpearth flows. Among the largest of them were the earth flow of San Giorgio la Molara (Benevento), which affected the course of the Tammaro River, the earth flow of Acquaviva di Isernia, the rotational slide at San Bartolomeo in Galdo (Benevento), and a rotational slide-flow at Calitri (Avellino) (Esposito et al. 1987, 1998).

The 1857 December 16 Basilicata earthquake (Ms 1/4 7.0; $\mathrm{I}_{0} 1 / 4 \mathrm{X}$-XI MCS scale; $\mathrm{I}_{0} 1 / 4 \mathrm{X}$-XI ESI) caused extensive damage over an exceptional large area; high values of intensities, $\mathrm{X}$ and XI MCS, were observed over an area of $900 \mathrm{~km}^{2}$, killing about 13,000 people and causing severe damages to man-made works and to the environment.

This event was characterized by multiple main shocks; the second shock, felt two minutes after the first one, with higher energy (Branno et al. 1985). Earthquake-induced environmental effects were recorded over a large area extending from the Vallo di Diano (Campania) to the Val d'Agri (Basilicata).

Primary and secondary geological effects were recognized both in the near and far field. Forty-three landslides phenomena have been localized and classified. The most common slides were rock fall (Atena Lucana, Teggiano, Montesano sulla Marcellana, Grumento Nova, Marsico Vetere) and topless and subordinately rotational slides (Viggiano, Polla), earth flows (Pignola), and slump earth flows (Bella, Muro Lucano), Mallet (1861), Esposito et al. (1998), Porfido et al. (2002).

On 1905 September 8, a large earthquake (Ms 1/4 7.1; $\mathrm{I}_{\mathrm{o}} 1 / 4 \mathrm{XI}$ MCS; $\mathrm{I}_{0} 1 / 4 \mathrm{X}$-XI ESI) occurred in the Southern part of the Calabria region. It extensively ruined several villages located in the northern part of the Capo Vaticano peninsula within an area that suffered a MCS intensity greater than IX, causing the death of 557 people. The earthquake was characterized by different epicenters both inland, near to Vibo Valentia, and offshore not far from the coastline, suggesting as capable faults the Vibo and Capo Vaticano normal fault segments (Catalano et al. 2008).

The event induced a great number of effects on the environment in a wide area: large landslides, accompanied by several cracks and fractures and liquefaction features occurred in several places within the epicentral area, hydrological variation (changes in flow and in the temperature of springs and rivers) were also observed over the entire Calabria region both in the near and far field. This event also generated a tsunami that inundated the whole northern coast of the peninsula from Vibo to Tropea with an estimated height of waves of about $1-2 \mathrm{~m}$.
The earthquake triggered at least 40 slides: mainly slump 228 earth flows (Belmonte Calabro, Caraffa di Catanzaro, 229 Cessaniti, Gizzeria, Martirano, Piscopio, Mileto ecc.) and 230 subordinately rock falls (Aiello Calabro, Caulonia, Conidoni, 231 San Leo, Tiriolo, Zungri) (Chiodo and Sorriso-Valvo 2006; 232 Tertulliani and Cucci 2008; Porfido et al. 2011). 233

The 1908 December 28 Southern Calabria-Messina 234 earthquake (Ms 1/4 7.2; I $1 / 4$ XI MCS; I $1 / 4$ X-XI ESI) is 235 one of the strongest seismic events that struck Italy during 236 the XXth century and the most ruinous in terms of casualties 237 (at least 80,000). The epicenter was located at sea in the 238 Messina Straits. The location of seismogenic fault is still an 239 open issue (Valensise et al. 2008; Aloisi et al. 2009) and 240 therefore the corresponding distance was not evaluated. 241

The impact of the earthquake was particularly catastrophic 242 in Reggio Calabria and Messina cities, damages have been 243 more intense and widespread along the Calabrian coast, 244 between south of Reggio Calabria and south-west of Scilla 245 (Comerci et al. 2009; Porfido et al. 2011). In Sicily the most 246 damaged area was the coast from its easternmost tip to south 247 of Messina. Some minutes after the earthquake, a destructive 248 tsunami inundated both sides of the Strait, with a run up that 249 rose above $10-13 \mathrm{~m}$.

More than 400 environmental effects were catalogued (Caciagli 2008; Comerci et al. 2009). Among them, particularly relevant were the changes in elevation along both sides of the Strait, partly due to the settlement of loose sediments and artificial filling (e.g., Messina and Reggio Calabria harbor areas), and partly ascribed to landslides and tectonic slip. Portions of the coast were lost, especially on the Calabrian side, most of them eroded by the tsunami. Landslides and rockfalls occurred in many Sicilian and Calabrian localities (especially between Reggio C. and Bagnara C.). A submarine telephone cable between Gallico (Calabria) and Gazzi (Sicily) was cut likely by a slide.

The 1930 July 23 Irpinia earthquake (Ms 1/4 6.7; I 1/4 X MCS; $\mathrm{I}_{\mathrm{o}} 1 / 4$ IX-X ESI) occurred in the most seismic part of the Southern Apennines. The earthquake affected a wide area of $36,000 \mathrm{~km}^{2}$, comprising the regions of Campania, Puglia and Basilicata. The studies of seismically-induced ground effects benefited from numerous historical and scientific sources, and allowed recognition of primary effects (surface faulting), secondary effects (fractures, landslides, settlements, hydrological changes, variations in the chemical and physical activity related to the volcanic and/or thermal zones).

The earthquake caused many sliding phenomena, which mainly affected the rural area and, to a lesser extent, the towns around the epicentral area. At least, 26 landslides were triggered by the earthquake. Large landslides struck Aquilonia (Avellino) and San Giorgio la Molara (Benevento). The former was a reactivation of a slump-earth flow, along the north side of the Rione San Pietro, that forced the abandonment of the entire village (Esposito et al. 2000a). The latter was a $1 \mathrm{~km}$ 250 251 252 253 254 255 256 257 258 259 260 261 262 263 264 265 266 267 268 269 270 271 272 273 274 275 276 277 278 279 280 0 1

3

34

35

6

38

39

40

41

42

43

44

45

46

48

\section{9}


wide and $3 \mathrm{~km}$ slump within the Argille Varicolori formation, on the left bank of the Tammaro River, that dammed a short section of the river. Other noteworthy landslides occurred at Ariano Irpino, Vallata, Montecalvo Irpino, Lacedonia, Rocchetta S. Antonio and Acerenza (Esposito et al. 1998; Porfido et al. 2002).

The 1980 November 23 Campania-Basilicata earthquake (Ms 1/4 6.9; $\mathrm{I}_{\mathrm{o}} 1 / 4 \mathrm{X}$ MCS; $\mathrm{I}_{\mathrm{o}}$ 1/4 X ESI) affected 800 localities over a large area of the Southern Apennines, killing 3,000 people. This event was felt nearly everywhere in the Italian peninsula, from Sicily to Emilia Romagna and Liguria (Postpischl et al. 1985).

The review of more than 100 technical and scientific publications has allowed to locate and classify 200 landslides over a total area of $22,000 \mathrm{~km}^{2}$. About $47 \%$ of the landslides were rock falls/toppling, $20 \%$ rotational slides, $20 \%$ slumpearthflows, $3 \%$ rapid earth flows, $9 \%$ left undefined (Cotecchia 1986; Esposito et al. 1998; Porfido et al. 2002, 2007). The largest rock falls occurred mostly in the epicentral area, with volumes ranged from 1,000 to $10,000 \mathrm{~m}^{3}$ as well as slump-earth flow that affected some historical centre in the Apennines. The largest one (23 million $\mathrm{m}^{3}$ ) affected Calitri (Avellino) and its recent urban expansion. Even larger were the mudflows at Buoninventre $\left(30\right.$ million $\left.\mathrm{m}^{3}\right)$, near Caposele and Serra d'Acquara, Senerchia (28 million $\mathrm{m}^{3}$ ).

The September-October 1997 Colfiorito seismic sequence (Mw 1/4 6.0; I $\mathrm{I}_{\mathrm{o}}$ o 1/4 VIII-IX MCS; I $1 / 4$ VIII-IX ESI) struck the Umbria and Marche regions (Central Italy). Three main events occurred on 26 September at 00:33 and 09:40 GMT, and 14 October with magnitude Mw equal to 5.8, 6.0 and 5.4, respectively; furthermore hundreds of minor but significant events were also recorded. Primary and secondary effects were observed, including surface faulting phenomena, landslides, ground fractures, compaction and various hydrological phenomena.

Landslides, which were the most recurrent among the phenomena induced, consisted mainly of rock falls (Stravignano Bagni, Sorifa, Val Nerina), and subordinately of rotational (Afrile, Foligno, Acciano, Monte d'Annifo), which were generally mobilised by the inertia forces during the seismic motion (Esposito et al. 2000; Guerrieri et al. 2009; Guzzetti et al. 2009).

On 1998 September 9, a moderate earthquake (Mw 1/4 5.7; I I 1/4 VII MCS; I 1/4 VIII ESI) hit the Southern Apennines at the NW margin of the Pollino Massif, between Basilicata and Calabria regions. Historical towns, such as Lagonegro, Lauria and Castelluccio suffered significant damage (I 1/4 VIII MCS). Several ground effects followed the shock, and a rock fall, far from the epicenter, on the road between Cersuta and Acquafredda claimed one life.

Landslide phenomena consisting in rock fall, toppling, rotational slides and earth slumps were observed in Castelluccio Inferiore and Superiore, Fardella, Lauria,
Maratea, Monte Alpi, Nemoli, Noepoli, Rivello, Rotonda, 334 Tortora. Trecchina and Viggianello territories (Michetti et al. 335 2000).

The 2002 October 31, San Giuliano di Puglia, earth- 337 quake (Mw 1/4 5.8; I I 1/4 VII-VIII MCS; I I I/4 VIII ESI) 338 caused relevant damages to some villages in Southern 339 Molise (San Giuliano di Puglia, Bonefro, Colletorto), 340 including the tragic collapse of a school at San Giuliano 341 that killed 27 children.

Environmental effects (Vittori et al. 2003) included mainly ground cracks, but also slope movements and hydrological anomalies. Seismically induced landslides consisted mainly in rotational slides (e.g. Castellino sul Biferno) but also translational slides even at significant distance from the epicenter (e.g., Salcito). Rock falls were not surveyed in a systematic way.

The 2009 April 6 L'Aquila earthquake (Mw 1/4 6.3; MCS I $1 / 4$ IX; ESI I $I_{0}^{1 / 4}$ IX), which rocked the Abruzzo region, in Central Apennines is part of a seismic sequence active from December 2008 to October 2009. The epicenter for the main shock was located near L'Aquila. Two M > 5 aftershocks followed on 7 April (ML 5.3, Mw 5.6, epicenter about $10 \mathrm{~km}$ southeast of L'Aquila) and on 9 April (ML 5.1, Mw 5.4, epicenter near Lake Campotosto).

Damages were concentrated on the historical town of L'Aquila which, together with many villages in the surrounding area. The death toll reached 308.

The earthquake produced a widespread set of geological effects on the natural environment. Clear evidence of surface faulting was found along the Paganica fault (Guerrieri et al. 2010; Vittori et al. 2011), and secondary effects have been mapped over an area of about $1000 \mathrm{~km}^{2}$, mostly gravitational movements and ground fissures, and secondarily liquefactions and hydrological anomalies (Blumetti et al. 2009).

Regarding slope movements, rock falls in calcareous slopes (Fig. 4) and artificial cuts have been the most common type of effect Sliding phenomena have also occurred, threatening in some cases the viability of important roads. The scenario includes also some local peculiar effects, like the ground failures along the shores of the Lake Sinizzo.

\section{Empirical Relationships}

Similarly to Keefer (1984), we have measured for each 377 earthquake the maximum distance of coseismic slides and 378 rock falls from either the causative fault and the epicentre (Table 1).

Then, such distances have been plotted versus magnitude and versus ESI epicentral intensity (Figs. 5 and 6) with the aim to find a potential correlation. 335

336 8

39



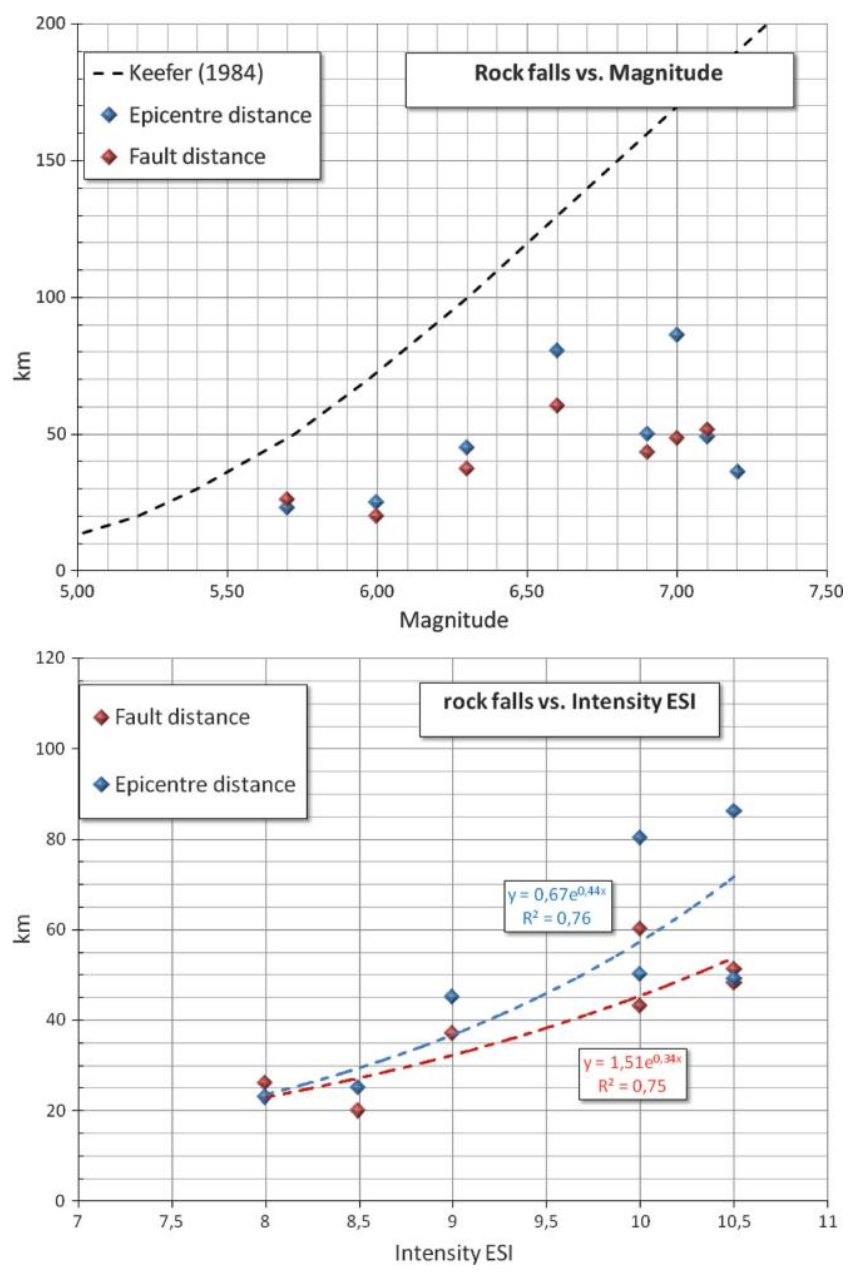

Fig. 6 Maximum fault distance (in red) and epicentral distance (in blue) of rock falls versus magnitude (above) and versus ESI epicentral intensity (below). Bold dashed line in the upper graph is the envelope curve of Keefer (1984). The point distribution is too scattered here to assess reliable trend lines parameters or damage-based intensity assessments, we stress here the usefulness of such a tool to define the expected scenario of earthquake-induced landslides, especially in sparsely populated areas or where seismic hazard assessment is based only on pre-instrumental seismicity. However, the data base needs to be improved and enlarged to allow more robust estimates.

References 432 AU6

Aloisi M, Ferranti L, Mattia M, Monaco C (2009) A new analitical approach to the modelling of the 1908 earthquake source (Messina Straits) from the inversion of the 1897/1906-1909 levelling data: comparison with geological data. Riassunti estesi della Sessione 1.1, GNGTS

Blumetti AM, Dramis F, Michetti AM (1993) Fault generated mountain fronts in the Central Apennines (Central Italy): geomorphological features and seismotectonic implications. Earth Surf Process Landf 18:203-223

Blumetti AM, Comerci V, Di Manna P, Guerrieri L, Vittori E (2009) Geological effects induced by the L'Aquila earthquake (6 April 2009; ML_5:8) on the natural environment, Preliminary Report, 38p. http://www.apat.gov.it/site/_files/Inqua/2009_abruzzo_earth quake_report.pdf

Bommer JJ, Rodriguez CE (2002) Earthquake-induced landslides in Central America. Eng Geol 63(3-4):189-220

Branno A, Esposito E, Ferrari G, Maturano A, Porfido S, Rinaldis V, Stucchi M (1985) The Irpinia earthquake of November 23, 1980. In: Postpischl D (ed) Atlas of isoseismal maps of Italian earthquakes, vol 114 (2A), Quaderni de la Ricerca scientifica. Consiglio nazionale delle ricerche, Progetto finalizzato geodinamica, Bologna, pp 152-157

Caciagli M (2008) Le tracce del terremoto del 1908 nell'ambiente naturale. In: Bertolaso G, Boschi E, Guidoboni E, Valensise G (eds) Il terremoto e il maremoto del 28 dicembre 1908: analisi sismologica, impatto, prospettive. DPC - INGV, Roma, pp 197-214

Catalano S, De Guidi C, Monaco C, Tortorici G, Tortorici L (2008) Active faulting and seismicity along the Siculo-Calabrian Rift Zone (Southern Italy). Tectonophysics 453:177-195

Chiodo G, Sorriso-Valvo M (2006) Frane sismo-indotte: casistica e fenomeni innescati dal terremoto dell' 8 settembre 1905. In: Guerra I (ed) 8 settembre 1905 - Terremoto in Calabria, Deputazione di Storia Patria della Calabria, Università della Calabria, Regione Calabria, pp 207-224

Comerci V, Blumetti AM, Brustia E, Di Manna P, Esposito E, Fiorenza D, Guerrieri L, Porfido S, Serva L, Vittori E (2009) One century after the 1908 Southern Calabria - Messina earthquake (southern Italy): a review of the geological effects. In: European Geophysical Society (ed) Geophysical Research Abstracts, vol 10, EGU2008-A-00000, 2008. European Geophysical Society, Katlenburg-Lindau

Cotecchia V (1986) Ground deformation and slope instability produced by the earthquake of novembre 1980 in Campani and Basilicata. In: IAEG proceedings international symposium, problems seismic areas, vol 5, Bari, pp 31-100

Cotecchia V, Guerricchio A, Melidoro G (1986) The Geomorphogenetic crisis triggered by the 1783 earthquake in Calabria (Southern Italy). In: Estratto da Proceedings of the international symposium on engineering geology problems in seismic areas, vol 6, Bari

CPTI (2004) Catalogo Parametrico dei Terremoti Italiani Gruppo di Lavoro CPTI. Bologna, http://emidius.mi.ingv.it/CPTI99

D’Agostino, N., A. Avallone, D. Cheloni, E. D’Anastasio, S. Mantenuto, and G. Selvaggi (2008). Active tectonics of the Adriatic region from 
GPS and earthquake slip vectors, J. Geophys. Res. 113, no. B12413, doi 10.1029/2008JB005860.

Demangeot, J. (1965). Géomorphologie des Abruzzes Adriatiques. Mémoires et documents, Editions du Center National de la Recherche Scientifique, Paris, 403pp

Devoti R, Riguzzi F, Cuffaro M, Doglioni C (2008) New GPS constraints on the kinematics of the Apennines subduction, Earth Planet. Sci Lett 273:163-174. doi:10.1016/j.eps1.2008.06.031

Esposito E, Porfido S (2010) Gli effetti cosismici sull'ambiente fisico per la valutazione della vulnerabilità del territorio. In: Gizzi FT, Masini N (eds) Dalle Fonti all'Evento. Percorsi strumenti e metodi per l'analisi del terremoto del 23 luglio 1930 nell'area del Vulture. EESI, Napoli, pp 129-142. ISBN 978-88495-2050-7

Esposito E, Luongo G, Marturano A, Porfido S (1987) Il Terremoto di S. Anna del 26 luglio 1805. Mem Soc Geol It 37:171-191

Esposito E, Gargiulo A, Iaccarino G, Porfido S (1998) Distribuzione dei fenomeni franosi riattivati dai terremoti dell'Appennino meridionale. Censimento delle frane del terremoto del 1980. In: Proceedings conversion international prevention of hydrogeological hazards: the role of scientific research, Alba, vol. 1, CNR-IRPI, pp 409-429

Esposito E, Porfido S, Simonelli AL, Mastrolorenzo G, Iaccarino G (2000a) Landslides and other surface effects induced by the 1997 Umbria-Marche seismic sequence. Eng Geol 58:353-376

Esposito E, Porfido S, Iaccarino G, Tranfaglia G (2000) Terremoti e centri storici dell'Irpinia: gli effetti del terremoto del 1930. In: Proceedings GeoBen 2000, CNR-GNDCI 2133, Torino, pp $477-484$

Esposito E, Pece R, Porfido S, Tranfaglia G (2001) Hydrological anomalies connected to earthquakes in Southern Apennines (Italy). Nat Hazard Earth Syst Sci, EGS 1:137-144

Esposito E, Pece R, Porfido S, Tranfaglia G (2009) Ground effects and hydrological changes in the Southern Apennines (Italy) in response to the 23 July 1930 earthquake (MS1/46.7). Nat Hazard Earth Syst Sci 9:539-550

Guerrieri L, Tatevossian R, Vittori E, Comerci V, Esposito E, Michetti AM, Porfido S, Serva L (2007) Earthquake environmental effects (EEE) and intensity assessment: the inqua scale project. Boll Soc Geol Italiana 126:375-386

Guerrieri L, Blumetti AM, Esposito E, Michetti AM, Porfido S, Serva L, Tondi E, Vittori E (2009) Capable faulting, environmental effects and seismic landscape in the area affected by the Umbria-Marche (Central Italy) seismic sequence. Tectonophysics. doi:10.1016/j. tecto.2008.10.034

Guerrieri L, Baer G, Hamiel Y, Amit R, Blumetti AM, Comerci V, di Manna P, Michetti AM, Salamon A, Mushkin A, Sileo G, Vittor E (2010) InSAR data as a field guide for mapping minor earthquake surface ruptures: Ground displacements along the Paganica Fault during the 6 April 2009 L'Aquila earthquake. J Geophys Res 115: B12331. doi:10.1029/2010JB007579

Guidoboni E, Ferrari G, Mariotti D, Comastri A, Tarabusi G, Valensise G (2007) CFTI4Med, catalogue of strong earthquakes in Italy (461 B.C.-1997) and Mediterranean area (760 B.C.-1500). http:// storing.ingv.it/cfti4med/

Guzzetti F, Esposito E, Balducci V, Porfido S, Cardinali M, Violante C, Fiorucci F, Sacchi M, Ardizzone F, Mondini A, Reichenbach P, Rossi M (2009) Central Italy seismic sequence-induced landsliding: 1997-1998 Umbria-Marche and 2008-2009 L'Aquila Cases. In: Proceedings of the next generation of research on earthquakeinduced landslides: an international conference in Commemoration of 10th anniversary of the Chi-Chi earthquake, Taiwan, pp 52-61

Keefer DK (1984) Landslides caused by earthquakes. Bull Geol Soc Am 95:406-421
Mallet R. (1862) Great Neapolitan earthquake of 1857. The first 550 principles of observational seismology, Chapman and Hall, London, 1862, 2 vols

Michetti AM, Ferreli L, Esposito E, Porfido S, Blumetti AM, Vittori E, Serva L, Roberts GP (2000) Ground effects during the 9 September 1998, Mw 1/4 5.6 Lauria earthquake and the seismic potential of the "Aseismic" Pollino region in Southern Italy. Seismol Res Lett $71: 31-46$

Michetti AM, Esposito E, Guerrieri L, Porfido S, Serva L, Tatevossian R, Vittori E, Audemard F, Azuma T, Clague J, Comerci V, Gurpinar A, McCalpin J, Mohammadioun B, Morner NA, Ota Y, Roghozin E (2007) Intensity scale ESI 2007. In: Guerrieri L, Vittori E (eds) Memorie descrittive carta geologica d'Italia, vol 74. APAT, Servizio Geologico d'Italia-Dipartimento Difesa del Suolo, Roma, p 53

Papadopoulos GA, Plessa A (2000) Magnitude-distance relations for earthquake-induced landslides in Greece. Eng Geol 58(3-4):377-386

Patacca E, Sartori R, Scandone P (1990) Tyrrhenian basin and Apenninic arcs. Kinematic relations since late Tortonian times. Mem Soc Geol Italiana 45:425-451

Porfido S, Esposito E, Vittori E, Tranfaglia G, Michetti AM, BlumettI AM, Ferreli L, GuerrierI L, Serva L (2002) Areal distribution of ground effects induced by strong earthquakes in the southern Apennines (Italy). Surv Geophys 23:529-562

Porfido S, Esposito E, Vittori E, Tranfaglia G, Guerrieri L, Pece R (2007) Seismically induced ground effects of the 1805, 1930 and 1980 earthquakes in the Southern Apennines (Italy). Boll Soc Geol Italy (Italy J Geosci) 126(2):333-346

Porfido S, Esposito E, Molisso F, Sacchi M, Violante C (2011) Earthquake-induced environmental effects in coastal area : some example in Calabria and Sicily (Southern Italy). Marine reSEArch@CNR.it (in press)

Postpischl D, Branno A, Esposito E, Ferrari G, Maturano A, Porfido S, Rinaldis V, Stucchi M (1985) The Irpinia earthquake of November 23, 1980. In: Postpischi D (ed) Atlas of isoseismal maps of Italian earthquakes, vol 114 (2A). CNR-PFG, Bologna, pp 152-157

Prestininzi A, Romeo R (2000) Earthquake-induced ground failures in Italy. Eng Geol 58(3-4):387-397

Roberts GP, Michetti AM (2004) Spatial and temporal variations in growth rates along active normal fault systems: an example from the Lazio-Abruzzo Apennines, central Italy. J Struct Geol 26:339-376. doi:10.1016/S0191-8141(03)00103-2

Rodriguez CE, Bommer JJ, Chandler RJ (1999) Earthquake induced landslides: 1980-1997. Soil Dyn Earthq Eng 18(1999):325-346

Serva L, Esposito E, Guerrieri L, Porfido S, Vittori E, Comerci V (2007) Environmental effects from five hystorical earthquakes in Southern Apennines (Italy) and macroseismic intensity assessment: contribution to INQUA EEE scale project. Q Int 173-17:30-44

Silva PG, Rodríguez Pascua MA, Pérez-López R, Bardaji T, Lario J, Alfaro P, Martínez-Díaz JJ, Reicherter K, Giménez García J, Giner J, Azañón JM, Goy JL, Zazo C (2008) Catalogacion de los efectos geologicos y ambientales de los terremotos en Espana en la Escala ESI 2007 y su aplicacion a los estudions paleosismologicos. Geotemas 6:1063-1066

Tertulliani A, Cucci L (2008) Fenomeni associati al terremoto della Calabria dell' 8 settembre 1905. Quaderni di Geofisica 60:4-17

Valensise G, Basili R, Burrato P (2008) La sorgente del terremoto del 1908 nel quadro sismo tettonico dello Stretto di Messina. In: Bertolaso G, Boschi E, Guidoboni E, Valensise G (eds) Il terremoto e il maremoto del 28 dicembre 1908: analisi sismologica, impatto, prospettive. INGV-DPC, Roma, pp 161-182

Vittori E, Deiana G, Esposito E, Ferreli L, Marchegiani G, Mastrolorenzo G, Michetti AM, Porfido S, Serva L, Simonelli AL, Tondi E (2000) Ground effects and surface faulting in the September-October 1997 55 
Umbriarche (CentraItaly) seismic sequence. J Geodyn 29:535-564

VittoriE, Comerci V, Guarneri E, Guerrieri L, Ligato D (2003) I terremoti del 31 ottobre e 1 novembre 2002 nel Molise orientale. In: Le attività APAT a seguit) di emergenze alluvionali e sismiche (Settembre 200ßjennaio 2003). APAT, Serie Rapporti 35/2003, 180pp
Vittori E, Di Manna P, Blumetti AM, Comerci V, Guerrieri L, 621 Esposito E, Michetti AM, Porfido S, Piccardi L, Roberts GP, 622 Berlusconi A, Livio F, Silea G, Wilkinson M, McCaffrey K, 623 Phillips RJ, Cowie PA (2011) Surface Faulting of the 6 April 624 2009 Mw 6.3 L'Aquila Earthquake in Centra! Italy. Bull Seismol 625 Soo Am 101(4). dodO20100140 